\title{
Serum Biochemistry of West African Dwarf Goats Fed, Some Browse Species Supplemented with a Concentrate Diet
}

\author{
Oyibo Amina ${ }^{1, ~ *, ~ E f i e n o k u ~ J u d e ~}{ }^{2}$, Shettima Ibrahim ${ }^{3}$, Umar Abdullahi Yaro ${ }^{4}$, \\ Ahmed Sule Hassanatu ${ }^{5}$, Emmanuel Amanabo Theophilus ${ }^{6}$, Adamu Abdulmajid Tsobaza ${ }^{1}$ \\ ${ }^{1}$ Department of Animal Production, Kogi State University, Anyigba, Nigeria \\ ${ }^{2}$ Department of Science Laboratory Technology, Delta State Polytechnic, Ogwashi-Uku, Nigeria \\ ${ }^{3}$ Department of Animal Science, Federal University, Kashere, Nigeria \\ ${ }^{4}$ Department of Chemistry, Kogi State University, Anyigba, Nigeria \\ ${ }^{5}$ Department of Animal Science, University of Benin, Benin, Nigeria \\ ${ }^{6}$ Department of Animal Science, University of Ilorin, Ilorin, Nigeria
}

Email address:

oyiboamina@gmail.com (O. Amina)

${ }^{*}$ Corresponding author

\section{To cite this article:}

Oyibo Amina, Efienoku Jude, Shettima Ibrahim, Umar Abdullahi Yaro, Ahmed, Hassanatu Sule, Emmanuel Amanabo Theophilus, Adamu Abdulmajid Tsobaza. Serum Biochemistry of West African Dwarf Goats Fed, Some Browse Species Supplemented with a Concentrate Diet. Animal and Veterinary Sciences. Special Issue: Promoting Animal and Veterinary Science Research. Vol. 8, No. 2, 2020, pp. 41-44. doi: 10.11648/j.avs.20200802.11

Received: October 17, 2019; Accepted: February 17, 2020; Published: April 13, 2020

\begin{abstract}
Sixteen West African dwarf bucks) were allotted into four (4) treatments of four goats each. The goats were fed leaves fromGmelina, (Gmelinaaborea) Tamarind, (Tamarindusindicus, Neem (Azadirachtaindica) and Teak (Tectonagrandis) at $300 \mathrm{~g} /$ goat/day forTreatments 1, 2, 3 and 4 respectively and a concentrate supplement diet at 100 gper goat/dayfor a duration of thirty five (35) days. The experimental design was a completely randomized design, data were analysed using a one way analysis of variance and least significant difference to separate the significant means. Concentrate and browse samples were analysed using the methods of AOAC, the blood samples for serological studies were collected in sample bottles from the jugular veins of the goats, using needles and syringes. Values for daily supplement intake (75.33 - 94.43g), daily browse intake $(134.22-245.44 \mathrm{~g})$ and total daily feed intake $(225.53-339.87 \mathrm{~g})$ were significantly different at $5 \%$ level, values for urea $(0.84$ - 1.38Mmol/1), cholesterol, $(4.83$ - 6.02) creatinine $(16.00-18.50 \mathrm{~mol} / \mathrm{l}$, and blood sugar $(38.96-44.32 \mathrm{mg} / \mathrm{dl}) \mathrm{were}$ significantly different, alkaline phosphate values ranged from 56.93 - 58.20 and were not significantly different. It was therefore concluded that the four browse species were safe for the goats, nutrients in the concentrate diets and the four browse species were adequate for the goats. Gmelinaarborea was the most preferred by the goats in terms of intake, The four browse species were therefore recommended for goat feeding especially during the long dry season. Further research using other breeds and classes of goats as well as other species of ruminants such as sheep and cattle was also recommended.
\end{abstract}

Keywords: Serum, Bio-chemistry, Fed Intake, Concentrate, West African Dwarf Goats, Browse

\section{Introduction}

Inadequate feeding is a major setback to ruminant livestock production in Nigeria. This has also led to low milk and meat production, high mortality of young stock and low growth rate. [1]. The use of agro by-products as well as some browse plants that tend to retain their leaves during the dry season were recommended by Ocheja et. Al [2].

Blood bio chemical constituents reflect the physiologicalresponse of animals to its internal and external environments, which include feeds and feeding, [3] Blood biochemistrystudies are usually undertaken to establish the 
diagnostic baseline of blood characteristics for routine management practice of farm animals [4]

Whenusingnon conventional feeds, it is important to assess the health status of the animals because some are known to affect blood parameters. [5] A readily available and fast means of assessing the clinical and nutritional health status of the animals in feeding trial may be the use of blood analysis.

Endogenous substancesmight manifest through reduced protein utilization thereby, increasing the catabolism of amino acids which would be subsequently degraded into urea and creatinine [6].

Accurate determination of creatinine clearance is crucial to rational drug therapy because many drugs are either partially or totally eliminated by the kidney [7].

Fromthe forgoingblood bio chemical constituent analysis is imperative considering the fact that many by -products are now used to feed ruminant animals.

The aim of this work therefore was to assess the blood bio chemical profile of West African dwarf goats fed some browse species, supplemented with a concentrate diet

\section{Materials and Methods}

\subsection{Experimental Location}

The experiment was conducted at the Sheep and Goat unit of the Livestock Teaching and Research farm, Kogi State University, Anyigba. Anyigba is located in the derived Guinea Savannah zone of Nigeria on latitude $7^{\circ} 15^{\prime}$ and $7^{\circ} 29^{\prime} \mathrm{N}$ of the equator and longitudes $7^{\circ} 11^{\prime}$ and $7^{\circ} 32^{\prime} \mathrm{E}$ of the Greenwich meridian. The zone lies in the warm humid climate of the tropics with clearly marked wet and dry season in April to October and November to March respectively with annual rainfall ranging from $1400-1500 \mathrm{~mm}$ and an ambient temperature of about $25^{\circ} \mathrm{C}$ with the highest in March and April. The average altitude is 420 meters above sea level [8].

\subsection{Feed preparation, Experimental Animals and Management}

Sixteen growing West African dwarf bucks were used for the study. The animals were housed individually and treated with Ivomec, for endo and ecto parasite control at $0.3 \mathrm{ml}$ each and oxytetracycline, hydrochloric and procaine penicillin at $2.0 \mathrm{ml}$ each as prophylactic treatment. To provide a common health status. The browse species used for this experiment were obtained from within Kogi State University campus Anyigba, and wilted for 24 hours to reduce the moisture content before feeding. The concentrate components were cashew nut shell, Maize offal (MO), Bambara nut offal (BO), Fish offal (FO), Rice offal (RO), Wood ash (WA), Bone meal and Table salt as shown in Table 1 below. These ingredients were ground to desired texture. The goats were allotted to four (4) treatments in a Completely Randomized Design (CRD) Each treatment had four (4) goats. Each goat was fed $100 \mathrm{~g}$ of the supplement diet per day.

The leaves, Gmelina, (Gmelinaaborea) Tamarind, (Tamarindusindicus), Neem (Azadirachtaindica) and Teak
(Tectonagrandis) were wilted for 24 hours and fed at $300 \mathrm{~g}$ /goat/day for each treatment. The concentrate was fed 1 hour later.

Feed served the goats was weighed daily and the left over was also weighed and subtracted from the quantity of feed served to determine the feed intake. The goats were weighed in themorning before feeding each week. The study duration was thirty five (35) days, aftera preliminary feeding period of 7 days.

Table 1. Composition of Supplement Diet (\% Dry matter).

\begin{tabular}{ll}
\hline FEED INGREDIENTS & COMPOSITION \\
\hline Cashew nut shell (CNS) & 10.00 \\
Maize offal (MO) & 27.00 \\
Bambara nut offal (BO) & 48.00 \\
Fish offal (FO) & 5.50 \\
Rice offal (RO) & 5.00 \\
Wood ash (WA) & 1.00 \\
Bone meal & 2.00 \\
Table salt & 1.50 \\
Total & 100 \\
Calculated nutrient content: & \\
Crude protein & 18.50 \\
Gross energy (Kcal/kg diet) & 3083.00 \\
Crude fibre & 14.00 \\
Calcium & 0.40 \\
Phosphorus & 1.20 \\
\hline
\end{tabular}

\subsection{Blood Sample Collection}

The blood samples for serological studies were collected in sample bottles from the jugular vein of each goat using needles and syringes. The sample bottles contained ethylene diamine tetra acetic acid (EDTA) anticoagulant, the blood samples were centrifuged thus allowing the clear sample to be separated for testing.

The Serum was analyzed for creatinine, urea, alkaline phosphate cholesterol and bloodsugar according to the method of Baker and Silverton [9].

\subsection{Proximate and Mineral Analysis}

Samples of browse species and the supplement diet were analyzed for their proximateandmineral composition using standard procedure according toAOAC [10]

\subsection{Experimental Design and Statistical Analysis}

The experimental design was a completely randomized design (CRD). Data were analyzed using a one-way analysis of variance (ANOVA) and significant differences wereseparated using least significant difference (LSD) with the aid of SPSS version 16. 2006 edition at 5\% level of significance. [11]

\section{Results and Discussion}

\subsection{Proximate Composition of Browse and Concentrate Diet}

The proximate composition of the browse and concentratediet is summarized in Table 2. 
The protein content of the browse and concentrate diet were within the values of $12-18 \%$ recommended for growing ruminants in the tropics [12]. Theether extracts values for the browse were within recommended values, while that of the concentrate diet was above the values of $5-6 \%$ whichif exceeded may impede appetite and fibre digestion [13].

Table 2. Proximate Composition of browse and supplement (Drymatterbasis) (\%).

\begin{tabular}{|c|c|c|c|c|c|}
\hline Treatments & T1 & T2 & T3 & T4 & \\
\hline Parameters & $\begin{array}{l}\text { Gmelina, } \\
\text { (Gmelinaaborea) }\end{array}$ & $\begin{array}{l}\text { Tamarind, } \\
\text { Tamarindusindicus }\end{array}$ & $\begin{array}{l}\text { Neem } \\
\text { (Azadirachtaindica) }\end{array}$ & Teak (Tectonagrandis) & Concentratediet \\
\hline Crude Protein & 10.98 & 16.55 & 15.68 & 14.64 & 18.23 \\
\hline Crude Fibre & 10.80 & 17.50 & 15.66 & 14.88 & 16.80 \\
\hline Nitrogen Free Extracts & 51.12 & 52.06 & 54.01 & 52.23 & 53.85 \\
\hline Ether Extracts & 7.10 & 6.89 & 8.05 & 8.35 & 7.70 \\
\hline Ash & 19.10 & 15.80 & 16.60 & 15.25 & 3.42 \\
\hline
\end{tabular}

\subsection{Feed Intake Records}

The feed intake recordof the experimental goats is presented in Table 3.

Values for daily supplement intake, daily browse intake and total daily feed intake were significantly $(\mathrm{p}<0.05)$ different.

The daily supplement intake of $75.33-94.43 \mathrm{~g}$, and total daily feed intake of $253-399.87 \mathrm{~g}$ were higher than 44.65 $91.54 \mathrm{~g}$ and $216.75-258.99 \mathrm{~g}$ reported byBaker and Silverton [9] but lower than 130.74 - 210.37g (TDFI) reportedbyArigbede et. al. [14] who fed cassava leave based diets to West African dwarf goats, these discrepancies could be due to the type of concentrates and browse fed to the goats.

Table 3. Feed Intake Records.

\begin{tabular}{lllll}
\hline \multirow{2}{*}{ Parameters } & Treatments & & & \\
\cline { 2 - 5 } & $\mathbf{T}_{\mathbf{1}}$ & $\mathbf{T}_{\mathbf{2}}$ & $\mathbf{T}_{\mathbf{3}}$ & $\mathbf{T}_{\mathbf{4}}$ \\
\hline Daily Supplement Intake (g) & $94.43^{\mathrm{a}}$ & $91.30^{\mathrm{a}}$ & $75.33^{\mathrm{b}}$ & $82.40^{\mathrm{b}}$ \\
Daily Browse Intake (g) & $245.44^{\mathrm{a}}$ & $134.22^{\mathrm{c}}$ & $180.44^{\mathrm{b}}$ & 3.66 \\
Total Daily Feed Intake (g) & $339.87^{\mathrm{a}}$ & $225.53^{\mathrm{b}}$ & $255.76^{\mathrm{b}}$ & $175.24^{\mathrm{b}}$ \\
\hline
\end{tabular}

$\mathrm{a}, \mathrm{b}, \mathrm{c}$ Treatmentmeans on the same row with different superscripts differ significantly $(\mathrm{p}<0.05)$

SEM Standard Error of Means

\subsection{Serum Biochemical Profile of Experimental Goats}

The serum biochemical profiles of the experimental goats are presented in Table 4. The values for blood sugar, creatinine, urea and cholesterol showed significant $(\mathrm{p}<005)$ differences. However values for Alkaline phosphate ranged from $56.93-58.20 \mathrm{~m} / 1$ and were not significant $(\mathrm{p}>0.05)$. All the biochemicalparameters evaluated were within normal ranges reported for goats byBlood et. al. [15] significant, values for urea and cholesterol, as well as non significance $(\mathrm{p}>0.05)$ for creatinine, cholesterol and alkaline phosphate were reported for west African dwarf goats fed sun-dried cashew puip meal based diets by Okpanachi et. al [17]. Significant $(p<0.05)$ values for blood sugar, urea, alkaline phosphate and cholesterol as well as non significance $(p>0.05)$ for creatinine were reported for West African dwarf goats fed diets containing graded level, of cashew nutshell. By Ocheja et. al. [18.], ranges of $51.30-84.36 \mathrm{~m} / 1$ for alkaline phosphate and $17.17 \quad-20.40 \quad \mathrm{mmol} / \mathrm{litre}$ forcreatinine. were aiso reported by Ocheja et. al. [18]

Alkaline phosphate values of 98.15 - $116.95 \mathrm{~m} / \mathrm{lwas}$ reported for West African dwarf goats fed cassava peels meal supplemented with African yam bean byOzung et. al. [16], normalvalues for alkaline phosphaterange from $42-.77 .5 \mathrm{ul}^{-1}$ [15], higher creatinine values suggests muscular wastage.

Abnormally high alkaline phosphate is indicative of bone disease, liver disease, bile obstruction. Variation could also be due to feed, collection and handling of blood samples, genetic, environment, sex and age of animals. Abnormally high urea values indicate poor protein quality as well as poor protein utilization in animals. [16]

Table 4. Serum Biochemical Profile of Experimental Goats.

\begin{tabular}{|c|c|c|c|c|c|}
\hline \multirow{2}{*}{ Parameters } & \multicolumn{4}{|c|}{ Treatments } & \multirow{2}{*}{ SEM } \\
\hline & $T_{1}$ & $\mathbf{T}_{2}$ & $\mathbf{T}_{3}$ & $\mathbf{T}_{4}$ & \\
\hline Blood Sugar (mg/dl) & $44.32^{\mathrm{a}}$ & $38.96^{\mathrm{b}}$ & $39.76^{\mathrm{b}}$ & $40.00^{b}$ & 1.05 \\
\hline Creatinine $(\mathrm{mol} / \mathrm{l})$ & $16.00^{\mathrm{a}}$ & $18.35^{\mathrm{b}}$ & $18.50^{\mathrm{b}}$ & $18.16^{\mathrm{b}}$ & 0.58 \\
\hline Urea (mmol/l) & $0.84^{\mathrm{a}}$ & $1.32^{\mathrm{b}}$ & $1.36^{\mathrm{b}}$ & $1.38^{\mathrm{b}}$ & 0.30 \\
\hline Alkaline phosphate $\mathrm{m} / \mathrm{l}$ & 56.93 & 58.20 & 57.60 & 57.30 & 0.05 \\
\hline Cholesterol (mmol/l) & $6.02^{\mathrm{a}}$ & $4.85^{\mathrm{b}}$ & $4.83^{\mathrm{b}}$ & $4.88^{\mathrm{b}}$ & 0.32 \\
\hline
\end{tabular}

$\mathrm{ab}$, Treatment means on the same row with different superscripts differ significantly $(\mathrm{p}<0.05)$

SEMStandard Error of Means 


\section{Conclusion and Recommendations}

\subsection{Conclusion}

The nutrients in the concentrate diets were adequate for the goatsGmelinaarborea was the most preferred by the goats in terms of intake, it also had the best array of nutrients

All the browse species fed to the goats had no adverse effect on the blood biochemistry parameters tested in this study.

\subsection{Recommendations}

The browse species evaluated are recommended for feeding goats especially during the long dry season, further research should be carried out using other species of ruminants such as sheep and cattle.

\section{References}

[1] Malu-kagu H A, Zarak, H. K Abbo and I. D Mohammed Assessry the nutrictive value of some common tropical feeds for feeding Ruminants in a semi-Arid environment of Nigeria. Nig. j. Animal science andTechnology, 1 (1): 31-37.

[2] Ocheja, J. O, Oguche, G. H. E, Omata, S. B, Ode. CO and Oyibo A (2017) performance and haematological profile of growing warf goats fed concentrate diets supplemented with browse plants. J. Agric. prod. And Tech. 6: 27-32.

[3] Esonu, B. O, Emamelon, O. O, Udedible, A. B, Hobert. U and Iheukumere, (2001). Performance and blood chemistry of weaner pigs, fed raw mucuna (velvet bean) meal.. Trop Anim. prod invests. 4: 49-54.

[4] Daramola, J O Adelofe, A A, Fatoba, I A and Soladoye A I (2015). Heamatological and biochemical parameters of West African dwarf goats. livestock Research for Rural Development 17 (8); 2025.

[5] Olabanji, R. O, Farinu, G. O, Akinlade J. A, Ojebiyi O. O, Odunsi A. A. and Akingbade A. A (2007) Studies on Haematological and Serum biochemical characteristics of wearer rabbits fed different levels of wild sunflower (Tithoniadiversifolia) Hons A Grey) leaf - blood meal mixing International Journal of Agriculture and Rural Development, 4 (1 and 2): 80-89.

[6] Sathyamorthy, V., Kamalakannan, V. and Mothea, D. B. (1981). Influence of dietary raw green gram (PhaseolusaurcusRoxb) and green grain trypsin inhibitors on the activity of certain protein metabolic enzyme in rats. Animal Nutrition Metabolism, 25: 333- 340.
[7] Schalm, O. W, Jaine N. C. and Caroll E. J. (1975) Veterinary Haematology $3^{\text {rd }}$ Ed Lea and Febyal Philadelphia U.S.A. Pp. 22-24.

[8] Ifatimehin, O. O, and Ufuah M. E (2006) The effect of a spatial Structure on Rural Economy; A Case of Kogi State University on Anyigba and its EnvironsConfluence Journal of Environmental Studies 1 (2); 61-70.

[9] Baker F. S and Silverton R. E (1985) laboratory technology $5^{\text {th }}$ edition, Butter S. C London RP 481-494.

[10] AOAC (1995) Association of Official Analytical Chemists. Official methods of Analysis $16^{\text {th }}$ edition Washington, D. C. Pp. 1-20.

[11] SPSS, (2006) Statistical packages for social sciences. Version 16.0 SPSS Inc. Pp. 12-14.

[12] NRC, National Research Council, (1996). Nutrient requirements of beef cattle $7^{\text {th }}$ Rev. Ed. National Academy Press Washington, DC. P. 27.

[13] Maithison, G. W., McAlhster, T. A., Cheng, K. J., Dong, Y., Galbraith, J. and Dmytruk, O. (1997). Methane emissions from farm animals. Abstract of workshop on green house Gas Research in Agriculture, Saint Foy March 12 - 14, Pp. 40-45.

[14] Arigbede, A. O., Adedeji, O. Y., Falola, O. O. and Saka, A. A. (2012). Performance characteristics and nutrient intake of West African Dwarf Goats fed cassava leaf hay- based diets. Proceeding $17^{\text {th }}$ Annual Conference of Animal Science Association of Nigeria, Abuja $9^{\text {th }}-13^{\text {th }}$ September, 2012 Pp. $559-562$.

[15] Blood D. C Studdert V. P and Gay, C C (2007) Saunders Comprehensive Veterinary Dictionary $3^{\text {rd }}$ Edition Elselvier New York pp. 1964-1968.

[16] Ozung P. O and Anya M. I (2018). Performance and carcass characteristic of West African Dwarf goats fed cassava peel meal based diets supplemented with African yam bean concentrateInt. Journal of advances in Agric. Science and Tech 5 (7) 95-108.

[17] Okpanachi, U, Okpanachi GAC Kaye-J, Agu C. I and Odah E. O (2018), Haematological profile and serum biochemistry of West African Dwarf goats fed sun-dried yellow cashew pulp based dietsjournal of applied science 19: 319-324.

[18] Ocheja J. O, Ayoade J. A, Attah, S, Netala J. Ocheni j and Oyibo, (2016) Carcass characteristic of growing west African Dwarf Goats fed Diets containing graded levels of steamtreatedcashew nut shell. Animal and veterinary sciences 4 (31): $18-22$. 